\title{
JURISPRUNDENCÉ \\ UPAYA PERLINDUNGAN SUMBER DAYA GENETIK BERDASARKAN UNDANG-UNDANG NOMOR 13 TAHUN 2016 TENTANG PATEN
}

\author{
Devica Rully Masrur \\ Fakultas Hukum Universitas Esa Unggul \\ Jalan Arjuna Utara No.9, Kebon Jeruk, Jakarta 11510 \\ Tlp : (021) 5674152 \\ devica@esaunggul.ac.id
}

\begin{abstract}
ABSTRAK
Pemanfaatan Sumber Daya Genetik di beberapa negara saat ini semakin meningkat. Namun demikian pencurian Sumber Daya Genetik dan/atau Pengetahuan Tradisional untuk tujuan komersial (biopircay) dan penyalahgunaan pemanfaatan sumber daya genetik (misappropriation) juga semakin banyak. Rezim Hak Kekayaan Intelektual, khususnya Paten dan Perlindungan Varietas Tanaman tidak memberikan perlindungan yang cukup atas sumber daya genetik dan pengetahuan tradisional. Convention on Biological Diversity (CBD) 1992 memberikan kesempatan mengenai pengaturan perlindungan sumber daya hayati yang sudah mulai punah karena dimanfaatkan secara bebas oleh perusahaan-perusahaan farmasi dunia. Nagoya Protocol on Access to Genetic Resources and the Fair and Equitable Sharing of Benefits Arising from their Utilization to the CBD 2010 dan FAO International Treaty on Plant Genetic Resources for Food and Agriculture (ITPRFA) 2004 memberikan ketentuan mengenai akses sumber daya genetik yang dilakukan berdasarkan mutually agreed terms, prior informed consent dan fair and equitable of benefit sharing. Indonesia telah meratifikasi berbagai perjanjian internasional yang berkaitan dengan akses sumber daya genetik dan saat ini Indonesia telah mempunyai Undang-Undang Nomor 13 Tahun 2016 tentang Paten yang juga mengatur agar sumber daya genetik Indonesia terlindungi. Hadirnya Undang-Undang Nomor 13 Tahun 2016 tentang Paten melengkapi upaya-upaya pemerintah Indonesia dalam menyelamatkan sumber daya genetik dari biopiracy dan misappropriation. Dengan berbagai kebijakan Nasional saat ini, kita dapat menganalisis upaya-upaya yang tepat untuk memperkuat perlindungan sumber daya genetik di Indonesia dengan tetap membuka kerjasama dengan pihak asing untuk memanfaatkan bersama sumber daya genetik Indonea dengan adanya benefit sharing yang adil.
\end{abstract}

Kata kunci: sumber daya genetik, hak kekayaan intelektual, paten

\section{A. PENDAHULUAN}

Indonesia adalah negara yang memiliki kekayaan sumber daya hayati (megabiodiversity) terbesar kedua setelah Brazil (kurang lebih memiliki 30.000 spesies).1 Indonesia juga memiliki kekayaan pengetahuan tradisional dibidang obat-obatan yang sangat banyak dan beragam. Dalam hal ini Indonesia belum memanfaatkannya secara maksimal karena lemahnya pengetahuan, skill, profesionalisme SDM, dan dana yang tersedia. Sejak zaman dahulu, warisan sumber genetik dan pengetahuan tradisional Indonesia secara turun temurun dimiliki secara bebas oleh publik karena tidak ada ketentuan yang melindunginya. Kondisi ini justru dimanfaatkan oleh negara maju yang mempunyai

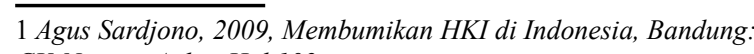
CV, Nuansa Aulia. Hal 102. kelebihan teknologi dan kemampuan finansial untuk mengambil kekayaan Indonesia dan kemudian dipatenkan oleh negara-negara maju.

Mengutip dari sebuah jurnal, Danniel M. Putterman berpendapat:

"Today, genetic resources are used primarily as the source of new, economically valuable chemical compounds, genes, or germplasm by industries in such sectors as pharmacenticals, agrochemicals, consumer products, ensymes, biotechnology, and seeds. The combined world market for pharmaceuticals alone exceeds $\$ 210$ billion annually"

Hal tersebut menunjukkan bahwa saat ini sumber

2 Daniel M. Putterman, , Model Material Transfer Agreement for Equitable Biodiversity Prospecting, 1996, Heinonline, Citation: 7 Colo. J. Int'l Envtl. L. \& Pol'y 149. Hal 1. 
daya genetik yang berupa senyawa kimia, gen, atau plasma nutfah oleh industri-industri di sektor farmasi, agro kimia, produk-produk konsumen, enzim, bioteknologi dan biji-bijian digunakan sebagai sumber utama yang sangat penting dan memiliki nilai ekonomi. Total untuk farmasi di pasar dunia saja melebihi 210 Milyar USD tiap tahun.

Pemanfaatan ekonomi dari sumber daya genetik dengan menggunakan bioteknologi, khususnya di bidang farmasi dan bioteknologi tidak dapat dipungkiri berkembang dengan dukungan sistem Hak Kekayaan Intelektual (HKI), khususnya dengan Paten dan Perlindungan Varietas Tanaman (PVT). Berdasarkan berbagai pertimbangan itu, kita dapat memanfaatkan SDG bersama-sama dengan sistem HKI untuk kepentingan dan kemajuan bangsa Indonesia. Melihat kondisi yang ada saat ini, ternyata sistem HKI belum mampu mendorong potensi ekonomi nasional dengan pemanfaatan SDG dan justru semakin meningkatkan terjadinya misappropriation atau biopiracy. ${ }^{3}$

Fakta mengenai adanya misappropriation atau biopiracy antara lain dapat dilihat pada persitiwa pendaftaran paten di Jepang atas beberapa sumber daya hayati dan pengetahuan tradisional Indonesia dibidang obatobatan oleh perusahan-perusahan Jepang. ${ }^{4}$ Apa yang dilakukan oleh perusahaan-perusahaan Jepang dengan mendaftarkan 'invensinya' di bidang obat-obatan itu boleh dikatakan merupakan penyalahgunaan, karena sesungguhnya invensi yang didaftarkan patenkan itu diambil dari apa yang telah oleh masyarakat di Jawa. Praktik misappropriation atas pengetahuan tradisional yang sudah ada di dalam masyarakat dan pengambilan bahan bakunya (biodiversity and genetic resources) oleh perusahaanperusahaan asing tidak saja terjadi di Indonesia, tetapi juga di beberapa negara berkembang lainnya. Salah satu kasus yang terkenal adalah Paten Pohon Neem (1996) milik masyarakat India oleh perusahaan Amerika. Beberapa peristiwa misappropriation dan biopiracy ternyata menjadi perhatian bagi negara-negara berkembang lainnya yang merasa dirugikan atas tidak adanya sistem perlindungan bagi sumber daya genetik dan kepemilikan bersama seperti local communities.

Hasil temuan penelitian atas sumber daya genetik berkaitan erat dengan hak paten karena sifatnya yang serupa dengan industrial property rights. Paten diberikan untuk setiap invensi, baik produk maupun proses, dalam semua bidang teknologi sepanjang invensi tersebut baru, mempunyai langkah inventif dan dapat diterapkan dalam industri. Article 27 ayat (3) TRIPs menyatakan bahwa "mikroorganisme baik yang telah ada di alam atau hasil rekayasa genetika merupakan subject matter yang patentable. TRIPs memungkinkan diberikannya hak paten untuk material genetika (dan produk-produk turunannya) asalkan memenuhi syarat kebaruan, langkah inventif dan

\footnotetext{
3 Dede Mia Yusanti, 2006, Perlindungan Sumber Daya Genetik Melalui Sistem Hak Kekayaan Intelektual, Direktorat Jenderal Hak Kekayaan Intelektual - Departemen Hukum dan HAM RI Tangerang-Banten 8 Nov 2006. www.digilib.litbang.deptan.go.id/repository/index.php/repository diakses pada 27 November 2013.

4 Daftar Paten Jepang sebagaimana dikutip dari Eupean Patent Website htttp://ep.espacenet.com. Dalam Agus Sardjono, 2006, Hak Kekayaan Tradisional dan Pengetahuan Tradisional, Bandung: PT. Alumni, hal 37.
}

dapat diterapkan dalam proses industri.

Perjanjian TRIPs (Agreement on Trade Related Aspects of Intellectual Property Rights) tidak mengatur mengenai penemuan (invensi) yang berasal dari sumber daya genetik, tetapi hanya mengakomodasi penemuan ilmiah (invensi) yang dalam hal ini dikategorikan sebagai paten. TRIPs memungkinkan diberikannya paten untuk material genetika (dan produk-produk turunannya) dan juga varietas tanaman tertentu, tetapi TRIPs tidak mengatur bagaimana hak paten atau varietas tanaman diperoleh, apakah konsisten atau tidak dengan hak negara (sovereignty) asal dari SDG tersebut.

Lahirnya Konvensi Keanekaragaman Hayati (Convention on Biological Diversity (CBD) 1992) yang dikenal sebagai Konvensi Keanekaragaman Hayati yang diadopsi dari KTT Bumi 1992 di Rio de Janeiro yang memberikan sedikit ruang mengenai pengaturan perlindungan sumber daya hayati yang sudah mulai punah karena dimanfaatkan secara bebas oleh perusahaan-perusahaan farmasi dunia.

Isu mengenai akses sumber daya genetik terus berlanjut dalam pembahasan di Convention on Biological Diversity (CBD)) ke-10, di Nagoya, Jepang 2010 yang menghasilkan Nagoya Protocol on Access to Genetic Resources and the Fair and Equitable Sharing of Benefits Arising from their Utilization to the CBD yang telah diratifikasi oleh Indonesia melalui Undang-Undang No. 11 tahun 2013. Tujuan protokol ini adalah untuk mengatur pembagian keuntungan yang adil dan merata yang timbul dari pemanfaatan sumber daya genetik agar dapat memberikan konstribusi terhadap konservasi dan pemanfaatan berkelanjutan dari keanekaragaman hayati dengan harapan adanya benefit sharing (pembagian hasil keuntungan) untuk negara asal sumber daya genetik itu.

Potensi sumber daya genetik yang besar di Indonesia diikuti dengan biopiracy dan misappropriation yang besar pula mengharuskan Pemerintah Indonesia membuat regulasi yang mengatur perlindungan terhadap sumber daya genetik yang lengkap dan terintegrasi. Selain amandemen Undang-Undang tentang Paten, alternatif lainnya adalah dengan membuat peraturan yang khusus mengatur tentang sumber daya genetik. ${ }^{5}$ Adanya berbagai regulasi setelah meratifikasi beberapa perjanjian internasional dianggap masih ada celah untuk terjadinya pencurian sumber daya genetik dan penyalahgunaan pemanfaatan sumber daya genetik di Indonesia.

Pada tahun 2016 Telah dibentuk Undang-Undang Paten yang baru, yaitu Undang-Undang Nomor 13 Tahun 2016 tentang Paten yang mencabut dan menggantikan Undang-Undang Nomor 14 Tahun 2001 tentang Paten. Berbeda dengan Undang-Undang Paten yang lama, di dalam Undang-Undang Nomor 13 Tahun 2016 mencantumkan ketentuan mengenai paten yang berasal dari sumber daya genetik, dalam Pasal 26 ayat (1) menyatakan bahwa "Jika Invensi berkaitan dengan dan/atau berasal dari sumber daya genetik dan/atau pengetahuan tradisional, harus disebutkan dengan jelas dan benar asal sumber daya genetik dan/atau pengetahuan tradisional tersebut dalam deskripsi." Dijelaskan dalam

5 Candra Purnama, 2016, Implementasi Undang-Undang No. 11 Tahun 2013 Dalam Mengatasi Biopiracy Di Indonesia, eJournal Ilmu Hubungan Internasional, 2016, 4 (1) 129-142 ISSN 2477-26 23, ejournal.hi.fisip-unmul.ac.id. diakses tanggal 18 Juni 2017 pukul 00.42 WIB 
penjelasan Pasal 26 ayat (1) bahwa "Alasan penyebutan asal dari sumber daya genetik dan/atau pengetahuan tradisional dalam deskripsi supaya sumber daya genetik dan/atau pengetahuan tradisional tidak diakui oleh negara lain dan dalam rangka mendukung Access Benefit Sharing (ABS)."

Paten adalah hak eksklusif yang diberikan oleh negara kepada inventor atas hasil invensinya di bidang teknologi untuk jangka waktu tertentu melaksanakan sendiri invensi tersebut atau memberikan persetujuan kepada pihak lain untuk melaksanakannya. Pemegang Paten mempunyai hak mutlak atas invensinya yang berlaku terhadap setiap orang. Hak atas invensi itu bersifat monopoli (exclusive right), artinya Pemegang Paten adalah satu-satunya yang dapat menggunakan haknya dan dapat pula melarang orang lain menggunakannya tanpa izin Pemegang Paten. Dengan diaturnya paten yang sumbernya berasal dari sumber daya genetik dan pengetahuan tradisional dalam Undang-Undang Paten, diharapkan segala pemanfaatan sumber daya genetik tidak disalahgunakan dan dimanfaatkan oleh pihak asing untuk diklaim hak patennya, serta adanya hak bagi Indonesia untuk tetap memiliki/menguasai dan mendapatkan pembagian keuntungan (benefit sharing) penemuan atau invensi yang sumbernya berasal dari sumber daya genetik Indonesia.

Pengaturan mengenai pendaftaran paten yang berasal dari sumber daya genetik dan/atau pengetahuan tradisional dalam Undang-Undang Nomor 13 Tahun 2016 tentang Paten membawa berbagai implikasi bagi perkembangan hak kekayaan intelektual di Indonesia di bidang paten dan juga berimplikasi bagi penerapan Access Benefit Sharing bagi Paten yang sumbernya berasal dari Indonesia. Lahirnya Undang-Undang Nomor 13 Tahun 2016 tentang Paten melengkapi upaya-upaya pemerintah Indonesia dalam menyelamatkan sumber daya genetik dari biopiracy dan misappropriation. Dengan mengkaitan dengan berbagai peraturan perundangundangan baik nasional maupun melalui instrumen internasional, dapat dikaji pula bagaimana upaya-upaya yang tepat untuk memperkuat perlindungan sumber daya genetik di Indonesia dengan berbagai regulasi yang telah ada. Dengan berdasarkan latar belakang tersebut, maka penulis tertarik melakukan penelitian yang berjudul tentang "Upaya Perlindungan Sumber Daya Genetik Berdasarkan Undang-Undang Nomor 13 Tahun 2016 tentang Paten.”

Berdasarkan uraian latar belakang di atas, maka terdapat beberapa pokok permasalahan yang akan dirumuskan dalam penelitian ini:

Bagaimanakah implikasi yuridis terhadap ketentuan mengenai perlindungan Sumber Daya Genetik dalam Undang-Undang Nomor 13 Tahun 2016 tentang Paten?

Bagaimanakah upaya-upaya yang dapat dilakukan untuk melindungi Sumber Daya Genetik di Indonesia melalui instrumen hukum internasional dan hukum nasional yang ada?

\section{B. METODE PENELITIAN}

Metode penelitian ini menggunakan pendekatan yuridis-normatif yaitu pendekatan atau penelitian hukum dengan menggunakan metode pendekatan teori atau konsep dan metode analisis yang termasuk dalam disiplin ilmu hukum yang dogmatis.6 Metode pendekatan yuridis normatif biasanya hanya merupakan studi dokumen, yakni menggunakan sumber-sumber data sekunder saja yang berupa peraturan perundang-undangan, keputusan pengadilan, teori hukum dan pendapat sarjana. Itupula sebabnya digunakan analisis secara kualitatif (normatif-kualitatif) karena datanya bersifat kualitatif.?

Dalam penelitian hukum normatif ini, penulis akan menggunakan pendekatan perundang-undangan atau Statute approach dan pendekatan konseptual atau conseptual approach. pendekatan perundangundangan dilakukan dengan menelaah semua peraturan perundang-undangan dan regulasi yang berkaitan dengan permasahan yang diteliti, kesesuaian dan konsistensi antara satu peraturan perundang-undangan yang satu dengan yang lainnya, dari peraturan perundangundangan yang tinggi ke yang rendah. Pendekatan konseptual akan memberikan pemahaman dengan menggunakan doktrin-doktrin yang berupa pendapat para ahli hukum. Dalam penelitian ini akan ditelaah seluruh peraturan perundang-undangan yang berkaitan dengan akses sumber daya genetik dan hak paten, dalam peraturan perundang-undangan tertinggi sampai yang paling rendah, baik instrumen hukum nasional maupun internasional, lalu dikaitkan dengan berbagai pendapatpendapat ahli tentang paten, hak kekayaaan intelektual dan sumber daya genetik.

\section{HASIL DAN PEMBAHASAN}

a.Implikasi Yuridis TerhadapKetentuanMengenai Perlindungan Sumber Daya Genetik Berdasarkan Undang-Undang Nomor 13 Tahun 2016 tentang Paten

Sumber daya genetik (SDG) atau genetic resources merupakan suatu bagian dari makhluk hidup yang sangat penting bagi kelangsungan hidup manusia. Jika hal ini dikaitkan dengan pangan, maka sumber daya genetika tumbuh-tumbuhan (plant genetic resources) menjadi tidak ternilai harganya sebagaimana diungkapkan oleh Stephen Brush (1994) sebagaimana dikutip oleh Dutfield (2002): ${ }^{8}$

"Plant genetic resourcces provide 'the foundation of all food production, and the key to feeding unprecedented members of people in times of climate and other environtmental change, and therefore comprise perhaps the most important catogory of biological resources."

Berdasarkan article 2 Convention on Biological Diversity (CBD), yang dimaksud dengan genetic resources adalah genetic material of actual or potential value.

WIPO menambahkan pengertian genetic material adalah "any material plant, animal, microbial or other origin containing functional units of heredity"

dimana functional units of heredity adalah semua organisme, dan ekstrak biokimia dari sampel jaringan (tissue) yang 6 Ronny Hanitijo Soemitro, Metodologi Penelitian Hukum dan Jurimetri, Ghalia Indonesia, Jakarta, 1990, hlm. 6

7 Soerjono Soekanto dan Sri Mamudji, 2010, Penelitian Hukum Normatif Suatu Tinjauan Singkat, Jakarta: PT Raja Grafindo Persada, halaman 24

8 Krisnani Setyowati, dkk. 2005, Hak Kekayaan Intelektual dan Tantangan Implementasinya di Perguruan Tinggi, Bogor: Kantor HKI - Institut Pertanian Bogor, hal 143. 
bermuatan deoxyribonuclei acid (DNA) atau untuk kasus tertentu ribonucleic acid (RNA) seperti gen, plasmids dan sebagainya. ${ }^{9}$

Sumber daya genetik merupakan karakter tumbuhan atau hewan yang dapat diwariskan, dapat bermanfaat atau berpotensi untuk dimanfaatkan manusia. Karena nilai sumber daya genetik yang demikian potensial, baik untuk kepentingan sosial dan ekonomi, banyak diskusi di tingkat regional dan internasional mengenai pemanfaatan dan perlindungan SDG. Dalam konteks pemanfaatan, sebelum ditandatanginya CBD, ada pemikiran bahwa keanekaragaman hayati di dunia ini merupakan warisan kemanusiaan (buman heritage/ common heritage), sehingga tanpa mempertimbangkan di mana beradanya SDG tersebut setiap orang dapat memanfaatkannya secara bebas. Namun pemikiran ini ditentang oleh negara yang memiliki dan memelihara SDG. Alasannya, sekalipun alam telah menyediakan SDG di lokasi tertentu, tetapi peran masyarakat setempat untuk melestarikan dan memanfaatkan SDG dimaksud besar, sehingga pengakuan terhadap masyarakat tersebut tetap harus diberikan dalam bentuk pemberian kewenangan pemanfaatan SDG dalam otoritas wilayahnya.

Article 3 CBD secara tegas menyatakan:

States have, in accordance with the Charter of the United Nations and the principles of international law, the sovereign right to exploit their own resources pursuant to their own environmental policies, and the responsibility to ensure that activities within their jurisdiction or control do not cause damage to the environment of other States or of areas beyond the limits of national jurisdiction.

Pasal 3 CBD tegas menyatakan bahwa negaralah yang mempunyai kewenangan untuk memanfaatkan sumber daya yang dimilikinya (termasuk SDG). Hal ini sangat sesuai dengan konstitusi Indonesia, Pasal 33 ayat (3) UUD 1945 bahwa "Bumi, air dan kekayaan alam yang terkandung didalamnya dikuasai oleh Negara dan dipergunakan untuk sebesar-besarnya kemakmuran rakyat".

Negara maju telah mendapatkan manfaat yang besar dari sumber daya genetika. Data dan fakta menunjukkan bahwa negara maju telah mendapatkan keuntungan berkisar US\$500 miliar-US\$800 miliar dari negara berkembang untuk produk farmasi. ${ }^{10}$ Sumber daya genetik tumbuhan juga memberikan sumbangan yang tak ternilai terhadap pertanian yang menopang kesejahteraan manusia di dunia. Mengingat luar biasanya peranan SDG tumbuhan bagi kelangsungan hidup manusia ini, Stepen Brush (1994) di dalam Dutfield $(2002)^{11}$ menyatakan bahwa sumber daya genetika tumbuhan merupakan dasar bagi semua produk pangan dan kunci untuk memberi makan manusia. Namun demikian, memperkirakan nilai ekonomi dari sumber daya genetika sangatlah sulit. Nilai ekonominya secara tidak langsung dapat diperkirakan dari nilai penjualan global atas produk-produk yang dihasilkan dari Sumber Daya Genetik.

Halyang menarik dalam perkembangan perlindungan

9 Loc. Cit.

10 Sardjono, 2004 dalam Krisnani Setyowati, dkk. 2005, Hak

Kekayaan Intelektual dan Tantangan Implementasinya di Perguruan Tinggi, Op. Cit. hal 148

11 Loc. Cit.
Hak Kekayaan Intelektual adalah adanya isu mengenai pentingnya perlindungan hak kekayaan Intelektual yang dimiliki oleh komunal, seperti Sumber Daya Genetik dan Pengetahuan Tradisional. Perlindungan Hak Kekayaan Intelektual berdasarkan persetujuan TRIPs ini lebih fokus pada perlindungan atas kepemilikan individual, bukan komunal. Meski demikian, sistem perlindungan Hak Kekayaan Intelektual terus dikembangkan melalui berbagai instrumen hukum nasional sesuai kebutuhan masing-masing negara.

Paten adalah hak eksklusif yang diberikan oleh negara kepada inventor atas hasil invensinya di bidang teknologi untuk jangka waktu tertentu melaksanakan sendiri invensi tersebut atau memberikan persetujuan kepada pihak lain untuk melaksanakannya. (Pasal 1 angka 1 Undang-Undang Nomor 13 Tahun 2016 tentang Paten). Menurut World Intellectual Property Organization (WIPO),

"A patent is legally enforceable right granted by virtue of a law to a person to exlude, for a limited time, other from certain acts in relation to describe new invention; the privilege is granted by a government authority as a matter of right ti the person who is entiled to apply for it and who fulfils the prescribed condition."

Pengertian di atas dapat dikaji unsur penting paten, yaitu hak paten adalah hak yang diberikan oleh pemerintah untuk melaksanakan penemuan dan bersifat ekslusif. Untuk mendapatkan paten; suatu penemuan harus memiliki syarat substantif tertentu, yaitu kebaruan (novelty), bisa dipraktikkan dalam industri (industrial applicability), mempunyai nilai langkah inventif (inventif step), dan memenuhi syarat formal.

Paten merupakan salah satu jenis Hak Kekayaan Intelektual yang paling erat kaitannya dengan pemanfaatan SDG. Ketentuan dalam sistem paten yang terkait dengan pemanfaatan SDG dan Pengetahun Tradisional terkait adalah:

a. Paten diberikan untuk setiap invensi, baik produk maupun proses dalam semua bidang teknologi sepanjang invensi tersebut baru, mempunyai langkah inventif dan dapat diterapkan dalam industri (Pasal 27 ayat (1) TRIPs dan Pasal UU No. 14 Tahun 2001 Tentang Paten).

b. Bahwa mikroorganisme baik yang telah ada di alam atau hasil rekayasa genetika merupakan subject matter yang patentable (Pasal 27 ayat (3) TRIPs).

Kedua pasal di atas menjadi penting dalam kaitannya dengan pemanfaatan SDG, karena: ${ }^{12}$

Perjanjian TRIPs memungkinkan diberikannya paten untuk material genetika (dan produk-produk turunannya) dan juga varietas tanaman tertentu;

Perjanjian TRIPs tidak mempunyai pembatasan bagi paten yang dihasilkan dari pengetahuan tradisional yang berarti bertentangan dengan Pasal 8(j) CBD;

12 Dede Mia Yusanti, Perlindungan Sumber Daya Genetik Melalui Sistem Hak Kekayaan Intelektual, Direktorat Jenderal Hak Kekayaan Intelektual - Departemen Hukum dan HAM RI. Tangerang-Banten 8 Nov 2006. Hal 55. 
a. Perjanjian TRIPs menyediakan perlindungan material genetika (dan produk-produk turunannya) melalui paten, tanpa memastikan bahwa ketentuan CBD yang meliputi prior informed consent dan benefit sharing dipertimbangkan.

Dalam Instrumen Persetujuan TRIPs, Sumber Daya Genetik merupakan bagian yang dilindungi oleh sistem Hak Kekayaan Intelektual, karena dalam dalam penemuan Sumber Daya Genetik dapat dipatenkan oleh penemunya. Akan tetapi TRIPs tidak memfasilitasi tentang pembagian keuntungan bagi negara pemilik Sumber Daya Genetik. Negara pemilik Sumber Daya Genetik tidak mendapatkan keuntungan ketika Sumber Daya Geneti Negara tersebut dipatenkan oleh Negara lain.

Melihat lebih lanjut tentang Perlindungan Sumber Daya Genetik ini diatur dalam instrumen internasional yaitu Convention on Biological Diversity (CBD) atau yang disebut dengan Konvensi Keanekaragaman Hayati yang merupakan konvensi yang diselenggarakan oleh Perserikatan Bangsa-Bangsa pada tanggal 5 Juni 1992 di Rio de Janiero, Brazil dan dalam CBD melahirkan suatu prinsip Access Benefit Sharing, yaitu sistem Pembagian keuntungan yang tepat dan adil atas penggunaan sumber daya genetik. Indonesia telah meratifikasi Convention on Biological Diversity (CBD) melalui Undang-Undang Republik Indonesia Nomor 5 Tahun 1994 Tentang Pengesahan United Nations Convention on Biological Diversity (Konvensi Perserikatan Bangsa-Bangsa Mengenai Keanekaragaman Hayati).

Dengan banyaknya kejadian misappropriation dan biopiracy atas sumber daya genetik, berkembang isu internasional bahwa sistem paten tidak sejalan dengan CBD, karena:

a. Hukum paten dalam TRIPs mengakui sumber daya genetik sebagai bagian dari subject matter yang dapat dipatenkan, tetapi hukum paten tidak mengatur bagaimana mendapatkan perlindungan paten terhadap sumber daya genetik. Selain itu, untuk pengetahuan tradisional, hukum paten tidak memberikan batasan secara jelas mengenai bentuk perlindungannya. Hal ini bertentangan dengan Pasal 8 (j) CBD.

b. Sistem paten tidak menjamin prior informed consent (PIC) dan Benefit Sharing sebagaimana yang disyaratkan dalam CBD, bahwa pemberian akses sumber daya genetik dilakukan berdasarkan kesepakatan bersama, persetujuan atas dasar informasi awal (prior informed consent) dan pembagian keuntungan yang adil dan sebanding atas pemanfaatan Sumber Daya Genetik tersebut.

c. Dalam hukum Paten tidak adanya suatu penghormatan atas kedaulatan (sovereignty) suatu negara dimana SDG berasal. Pasal 15 ayat (1) CBD memberikan pengakuan adanya kedaulatan negara sebagai pihak yang berwenang untuk menentukan akses sumber daya genetik berdasarkan peraturan perundang-undangan yang berlaku di negara di mana sumber daya genetik berasal.
Tindak lanjut dari Pasal 15 CBD adalah dikeluarkannya the Nagoya Protocol (NP in October 2010). Protokol Nagoya tentang Akses pada Sumber Daya Genetik dan Pembagian Keuntungan yang Adil dan Seimbang yang Timbul dari Pemanfaatannya atas Konvensi Keanekaragaman Hayati (Nagoya Protocol on Access to Genetic Resources and the Fair and Equitable Sharing of Benefits Arising from Their Utilization to the Convention on Biological Diversity) yang selanjutnya disebut Protokol Nagoya. Protokol Nagoya merumuskan aturan pelaksanaan CBD terkait pemberian akses dan pembagian keuntungannya. Penyedia kekayaan sumber daya hayati bekerja sama dengan pengguna dalam mekanisme pembagian keuntungan yang adil dan setara.

Protokol Nagoya merumuskan mekanisme pemanfaatan kekayaan sumber daya hayati yang berasal dari tanaman, hewan, dan mikrobiologi untuk produk industri, kosmetik, makanan, obat- obatan, dan keperluan lain. Intinya, terbuka akses pada sumber daya hayati untuk pemanfaatan, tetapi juga dalam semangat yang sama mengatur bagaimana manfaat atau keuntungan juga dapat dinikmati oleh negara asal sumber daya hayati itu. Kesepakatan diharapkan dapat membuat transparan pergerakan lalu lintas sumber-sumber daya hayati sehingga pembajakan hayati (biopiracy) dapat ditekan seminimal mungkin. ${ }^{13}$

Berkaitan dengan sumber daya genetik dan paten, Dutfield mengemukakan beberapa keberatan yang muncul berkenaan dengan kemungkinan menerapkan rezim paten bagi sumber daya genetik dan perlindungan pengetahuan tradisional. ${ }^{14}$ Pertama, paten merupakan perlindungan bagi individu yang kreatif yang menemukan hal-hal baru dalam bidang teknologi. Paten hanya diberikan kepada individu penemu, sementara itu sumber daya genetik dan pengetahuan tradisional tidak dimiliki oleh individu-individu tertentu, melainkan milik bersama dari masyarakat yang bersangkutan. Kedua, paten membutuhkan bukti-bukti tertentu mengenai penemuan yang bersangkutan, sementara sistem pegetahuan tradisional tidak mengenal bukti-bukti tersebut. Pembuktian dalam paten terutama dilakukan terhadap tiga syarat patentability, yaitu novelty, non-obviousness, dan industrial applicability. Masyarakat lokal tidak akan dapat membuktikan unsur novelty jika mereka menginginkan perlindungan paten atas pengetahuan tradisional mereka karena pengetahuan itu sendiri memang bukan sesuatu yang baru. Demikian pula mengenai pembuktian adanya inventive step, masyarakat akan menemui kesulitan karena pengetahuan itu mereka peroleh dengan meniru dari orang-orang terdahulu. Ketiga, paten mensyaratkan bahwa penemuan atau invensi yang dimintakan perlindungan paten harus dituangkan dalam bentuk dokumen (tulisan). Hal ini akan mempersulit para dukun untuk memperoleh paten karena mereka tidak memahami dan memiliki tradisi menulis sebagaimana dipersyaratkan dalam paten. Keempat, mengajukan permohonan paten dan melakukan enforcement atas hak paten itu memerlukan biaya yang tidak sedikit, sementara masyarakat tidak

13 http://jerryleopard-jerry.blogspot.com/2013/09/komersialisasi-sumber-daya-di-sektor.html diakses pada 3 Februari 2014 Pukul $00.31 \mathrm{WIB}$

14 Agus Sardjono, Op. Cit. Hal 89-91. 
mempunyai sumber daya tersebut. ${ }^{15}$ Berdasarkan hal tersebut, jelas bahwa menggunakan rezim paten untuk melindungi pengetahuan tradisional dan sumber daya genetik mengandung beberapa kelemahan, sebagai akibat perbedaan mendasar antara sistem paten dan pengetahuan tradisional yang bersangkutan.

Dari kedua instrumen internasional yang mengatur mengenai Sumber Daya Genetik dan Hak Kekayaan Intelektual, Indonesia telah meratifikasinya. Konsekuensi dari meratifikasi perjanjian internasional adalah kemauan Negara untuk menundukkan diri atas aturan yang ditentukan oleh perjanjian internasional tersebut dan menyesuaikan hukum nasionalnya sebagaimana diatur dalam perjanjian tersebut.

Bentuk Perlindungan Sumber Daya Genetik ini diatur dalam instrumen internasional yaitu Convention on Biological Diversity (CBD) telah diratifikasi melalui Undang-Undang Republik Indonesia Nomor 5 Tahun 1994 Tentang Pengesahan United Nations Convention on Biological Diversity (Konvensi Perserikatan Bangsa-Bangsa Mengenai Keanekaragaman Hayati). Namun demikian, Sumber Daya Genetik yang berkaitan dengan Paten di Indonesia diatur dalam Undang-Undang Paten, yaitu Undang-Undang Nomor 13 Tahun 2016. Regulasi baru tentang Paten dalam yaitu Undang-Undang Nomor 13 Tahun 2016 telah memuat mengenai perlindungan Sumber Daya Genetik. Selain atas dasar mengadopsi ketentuan dalam TRIPs dan CBD, juga Indonesia sebagai negara Mega Biodiversity terbesar kedua di dunia memang membutuhkan ketentuan tentang Sumber Daya Genetik dalam sistem Hak Kekayaan Intelektual. Hal ini juga dilatarbelakangi oleh banyaknya kasus misappropriation dan biopiracy atas sumber daya genetik yaitu pencurian Sumber Daya Genetik di Indonesia oleh pihak lain yang kemudian didaftarkan sebagai Paten, sementara Indonesia sebagai asal Sumber Daya Genetik tidak mendapatkan keuntungan apapun.

Sebagian besar sistem paten di dunia berdasarkan pada sistem first to file. Dalam sistem ini, perlindungan diberikan pada mereka yang pertama kali mengajukan permohonan dan jika penemuan memenuhi syarat paten akan mendapatkan paten. Pihak lain yang mengajukan permohonan paten atas penemuan yang sama, tidak akan mendapatkan perlindungan. Negara-negara yang menganut sistem first to file mensyaratkan pemohon menjadi pemohon paten pertama. Indonesia termasuk salah satu negara yang menganut sistem first to file pada paten. Sistem pendaftaran paten di Indonesia berdasarkan Undang-Undang Nomor 13 Tahun 2016 tentang Paten menggunakan first to file system, yang menyebabkan suatu penemuan atau invensi telah dimohonkan patennya akan mendapatkan perlindungan hukum semenjak diterimanya permohonan paten tersebut, karena sistem first to file menyatakan bahwa tanggal penerimaan paten adalah saat tanggal Direktorat Jendral HKI menerima surat permohonan paten yang telah memenuhi persyaratan minimum, yaitu yang berupa pemenuhan syarat-syarat administrasi. Hal tersebut dimaksudkan untuk memudahkan pemohon dalam memperoleh tanggal penerimaan yang sangat penting bagi status permohonan karena akan menentukan sejak kapan penemuan itu mendapatkan perlindungan hukum. 15 Dutfield, TRIPs-Related Aspects of Traditional Knowlede, hal 254 dalam Agus Sardjono, Op. Cit. hal 91.
Konsekuensi dari sistem first to file dalam penerimaan paten ini adalah bahwa setiap permohonan paten yang telah diajukan dan diterima maka secara otomatis telah mempunyai kekuatan hukum yang kuat, karena telah mendapatkan perlindungan hukum dari pemerintah walaupun terhadap penemuan yang dimohonkan paten itu belum dikeluarkan sertifikat patennya. ${ }^{16}$ Berkaitan dengan sifat perlindungan paten yang berdasarkan pada sistem first to file, konsekuensinya adalah akan banyak penemu yang segera mendaftarkan invensinya dan berlomba dengan pihak lain yang membuat penemuan yang sama untuk secepat mungkin mengajukan permohonan patennya ke pemerintah.

Secara umum, konsekuensi hukum akibat diberlakukannya Hak Kekayaan Intelektual adalah: Pemegang hak dapat memberikan izin atau lisensi kepada pihak lain.

a. Pemegang hak dapat melakukan upaya hukum baik perdata maupun pidana dengan masyarakat umum.

b. Adanya kepastian hukum yaitu pemegang dapat melakukan usahanya dengan tenang tanpa gangguan dari pihak lain.

c. Pemberian hak monopoli kepada pencipta kekayaan intelektual memungkinkan pencipta atau penemu tersebut dapat mengeksploitasi ciptaan/ penemuannya secara ekonomi.

d. Hasil dari komersialisasi penemuan tersebut memungkinkan pencipta karya intektual untuk terus berkarya dan meningkatkan mutu karyanya dan menjadi contoh bagi individu atau pihak lain, sehingga akan timbul keinginan pihak lain untuk juga dapat berkarya dengan lebih baik sehingga timbul kompetisi.

Menurut Pasal 19 ayat (1) Undang-Undang Nomor 13 Tahun 2016 tentang Paten, Pemegang Paten memiliki hak eksklusif untuk melaksanakan Paten yang dimilikinya dan untuk melarang pihak lain yang tanpa persetujuannya:

a. dalam hal Paten-produk: membuat, menggunakan, menjual, mengimpor, menyewakan, menyerahkan, atau menyediakan untuk dijual atau disewakan atau diserahkan produk yang diberi Paten;

b. dalam hal Paten-proses: menggunakan proses produksi yang diberi Paten untuk membuat barang atau tindakan lainnya sebagaimana dimaksud dalam huruf a.

Keuntungan pemegang hak paten adalah memonopoli penemuannya ialah untuk mendapatkan: ${ }^{17}$

a. kemanfaatan bagi diri sendiri, artinya sebagai pemegang suatu hak milik. Pemegang hak paten

16 Retna Gumanti, Perlindungan Hukum Terhadap Hak Paten Di Indonesia, Al-Mizan, ISSN 1907-0985 E ISSN 2442-8256 Volume 11 Nomor 1 Juni 2015 Halaman 196-210.

17 Ibid 
memiliki wewenang untuk mengambil manfaat dari penemuan itu bagi keuntungannya sendiri dengan cara-cara yang dibenarkan oleh hukum. Kemanfaatan itu dapat meliputi kemanfaatan di bidang materiil maupun di bidang immaterial.

b. Mengalihkan kemanfaatannya kepada orang lain, dalam bentuk mengijinkan, menyewakan, menjual, menghibahkan, ataupun mewariskan isi hak paten itu kepada orang lain.

c. Melarang orang lain yang tanpa hak memanfaatkan penemuan pemegang paten yang sah.

d. Melarang importasi atau eksportasi hasil dari penemuan itu yang dilindungi hak patennya, tanpa persetujuan dari pemegang paten yang sah.

Sifat perlidungan paten yang bersifat individual dan eksklusif ini berbeda dengan penlindungan sumber daya genetik yang dimiliki secara komunal. Atas penemuan paten yang sumbernya berasal dari sumber daya genetik, menjadi tidak berkeadilan manakala dimonopoli oleh penemunya saja sedangkan masyarakat atau negara asal sumber daya genetik tersebut diambil tidak memperoleh keuntungan apapun. Padahal pemilik paten dapat mengambil keuntungan sebesar-besarnya baik secara material dan immaterial selama perlindungan paten tersebut diberikan.

Dalam Undang-Undang Nomor 13 Tahun 2016, mengatur tentang Keharusan pengungkapan dengan jelas dan benar asal sumber daya genetik dan/atau pengetahuan tradisional dalam deskripsi paten (Nagoya Protokol utk ABS). Pasal 26 ayat (1) Undang-Undang Nomor 13 Tahun 2016 tentang Paten menyatakan bahwa "Jika Invensi berkaitan dengan dan/atau berasal dari sumber daya genetik dan/atau pengetahuan tradisional, harus disebutkan dengan jelas dan benar asal sumber daya genetik dan/atau pengetahuan tradisional tersebut dalam deskripsi." Berdasarkan uraian tersebut, ini menunjukkan bahwa Indonesia menetapkan regulasi tentang hak berdaulat negara-negara atas kepemilikan sumber daya genetik sebagaimana diamanatkan dalam Convention on Biological Diversity 1992. Selanjutnya, penjelasan Pasal 26 ayat (1) Undang-Undang Nomor 13 Tahun 2016 tentang Paten menyatakan bahwa alasan penyebutan asal dari sumber daya genetik dan/atau pengetahuan tradisional dalam deskripsi supaya sumber daya genetik dan/atau pengetahuan tradisional tidak diakui oleh negara lain dan dalam rangka mendukung Access Benefit Sharing (ABS). Ketentuan ini lahir sejalan dengan Nagoya Protocol sebagai tindak lanjut Pasal 15 Convention on Biological Diversity, Nagoya Protokol merupakan sebuah Rezim "akses dan pembagian keuntungan" (Access and Benefit Sharing Regime) untuk menentukan pengaturan mengenai bagaimana sumber daya genetik dapat diakses dan apa manfaat yang dihasilkan dapat dibagi antara individu, negara atau badan lainnya, pengaturan ditingkat nasional, regional maupun institusi global.

Diatur selanjutnya dalam Pasal 26 ayat (2) Undang-Undang Nomor 13 Tahun 2016 tentang Paten menyatakan bahwa "Informasi tentang sumber daya genetik dan/atau pengetahuan tradisional sebagaimana dimaksud pada ayat (1) ditetapkan oleh lembaga resmi yang diakui oleh pemerintah.” Selanjutnya dalam Pasal 26 ayat (3) Undang-Undang Nomor 13 Tahun 2016 tentang Paten menyatakan bahwa Pembagian hasil dan/ atau akses pemanfaatan sumber daya genetik dan/atau pengetahuan tradisional sebagaimana dimaksud pada ayat (1) dilaksanakan sesuai dengan peraturan perundangundangan dan perjanjian internasional di bidang sumber daya genetik dan pengetahuan tradisional. Ketentuan ini memberikan pengakuan adanya kedaulatan negara sebagai pihak yang berwenang untuk menentukan akses sumber daya genetik berdasarkan peraturan perundangundangan yang berlaku di negara di mana sumber daya genetik berasal, yaitu Indonesia.

Indonesia merupakan negara yang memiliki kekayaan sumber daya genetik dan pengetahuan tradisional yang sering dimanfaatkan oleh Inventor dalam maupun luar negeri untuk menghasilkan Invensi yang baru. Oleh karena itu, dalam Undang-Undang ini terdapat pengaturan mengenai penyebutan secara jelas dan jujur bahan yang digunakan dalam Invensi jika berkaitan dan/atau berasal dari sumber daya genetik dan/atau pengetahuan tradisional tersebut dalam deskripsi. ${ }^{18}$ Atas penyebutan Informasi tentang sumber daya genetik dan pembagian hasil dan/atau akses pemanfaatan sumber daya genetik sebagaimana dimaksud dalam Pasal 26 Undang-Undang Nomor 13 Tahun 2016 tentang Paten, telah mendukung maksud dan tujuan sebagaimana diatur dalam Protokol Nagoya, antara lain:

a. Memberikan akses dan pembagian keuntungan terhadap pemanfaatan sumber daya genetik dan pengetahuan tradisional terkait sumber daya genetik, termasuk pemanfaatan atau komersialisasinya serta produk turunannya (derivative);

b. Akses terhadap sumber daya genetik tersebut tetap mengedepankan kedaulatan negara dan disesuaikan dengan hukum nasional dengan berlandaskan prinsip prior informed consent (PIC) dengan pemilik atau penyedia sumber daya genetik; dan

\section{c. Mencegah pencurian sumber daya genetik (biopiracy).}

Pasal 132 ayat (1) Undang-Undang Nomor 13 Tahun 2016 tentang Paten menyatakan bahwa "Penghapusan Paten berdasarkan putusan pengadilan sebagaimana dimaksud dalam Pasal 130 huruf b dilakukan jika: (b) Paten yang berasal dari sumber daya genetik dan/atau pengetahuan tradisional tidak memenuhi ketentuan sebagaimana dimaksud dalam Pasal 26." Ini artinya bahwa paten yang telah didaftar dapat dihapuskan melalui putusan pengadilan jika paten tersebut berkaitan dengan dan/atau berasal dari sumber daya genetik dan/ atau pengetahuan tradisional tidak menyebutkan dengan jelas dan benar asal sumber daya genetik dan/atau pengetahuan tradisional tersebut dalam deskripsi.

Adapun keuntungan ekonomi juga dapat diperoleh berdasarkan ketentuan adanya Access Benefit Sharing

18 Penjelasan Umum Undang-Undang Nomor 13 Tahun 2016 tentang Paten. 
(ABS) atau akses dan pembagian keuntungan, untuk menentukan pengaturan mengenai bagaimana sumber daya genetik dapat diakses dan apa manfaat yang dihasilkan dapat dibagi antara individu, negara atau badan lainnya, pengaturan ditingkat nasional, regional maupun institusi global. Sehingga keuntungan ekonomi tidak hanya diperoleh oleh penemu saja, tetapi negara asal sumber daya genetik tersebut.

\section{b. Upaya-Upaya yang Dapat dilakukan untuk melindungi Sumber Daya Genetik di Indonesia Melalui Instrumen Hukum Internasional dan Hukum Nasional}

\section{Instrumen Hukum Internasional}

Salah satu tujuan Convention on Biological Diversity (CBD) adalah Pembagian keuntungan yang tepat dan adil atas penggunaan sumber daya genetik sebagaimana diatur dalam Pasal 15. Pasal 8 (j) CBD menentukan bahwa setiap negara peserta harus menghormati dan turut memelihara pengetahuan tradisional, kebiasaan yang hidup dalam masyarakat adat atau masyarakat lokal di suatu negara untuk menjaga konservasi dan kelangsungan sumber daya hayati.

Subject to its national legislation, respect, preserve and maintain knowledge, innovations and practices of indigenous and local communities embodying traditional lifestyles relevant for the conservation and sustainable use of biological diversity and promote their wider application with the approval and involvement of the holders of such knowledge, innovations and practices and encourage the equitable sharing of the benefits arising from the utilization of such knowledge, innovations and practices.

Perlindungan mengenai sumber daya genetik semakin berkembang setelah munculnya Convention on Biological Diversity pada tahun 1992 yang berkaitan dengan akses SDG sebagaimana dicantumkan dalam Pasal 15 CBD. Pasal 15 ayat (1) menyatakan "mengakui hak kekuasaan negara atas sumber daya alamnya", sehingga kekuasaan untuk menentukan akses terhadap SDG berada di tangan pemerintah dan bergantung pada undang-undang negara yang berlaku. Pengaturan akses tidak berarti membatasi akses, tetapi justru membuat persyaratan yang memfasilitasi akses SDG untuk pemanfaatan berkelanjutan dan yang ramah lingkungan dan mendorong pembagian keuntungan yang dihasilkan dari pemanfaatan SDG tersebut. ${ }^{19}$ Hal ini berarti telah ada pengakuan terhadap kedaulatan "local community" atas sumber daya alam di tingkat masyarakat pedesaan. Pengakuan kedaulatan tersebut adalah kekuasaan negara untuk menentukan akses SDG berdasarkan kebijakan pemerintah dan tunduk pada hukum nasional. bahwa:

Dalam sebuah jurnal, Peter-Thobias Stoll menyatakan

"an important rationale for the Act was to resolve the fragmented nature of biodiversity-related legislation; to facilitate cooperation between the different levels of government (national, provincial and local): and to give effect to constitutionally protected 19 Latar Belakang Pedoman Pengalihan Material (Material Transfer Agreement) Peraturan Menteri Pertanian environmental rights". ${ }^{20}$

Pasal 15 ayat (4) dari CBD menentukan bahwa di mana akses diberikan itu akan tunduk pada persyaratan yang disepakati bersama. Saat ini bentuk konvensional perjanjian akses adalah Material Transfer Agreement (MTA). Sejumlah ketentuan CBD mengacu pada pembagian yang adil dari keuntungan yang dihasilkan atas pemanfaatan sumber daya genetik yang telah disepakati. Jadi, CBD menetapkan bahwa akses terhadap SDG, apabila diberikan, harus didasarkan pada Pasal 15 ayat (4) dan ayat (5), yaitu:

a. Adanya kesepakatan bersama (Mutualyl Agreed Terms),

b. Persetujuan Atas Dasar Informasi Awal (Prior Informed Consent), dan

c. Pembagian keuntungan yang diperoleh dari pemanfaatan SDG secara adil dan sebanding, sebagaimana disebutkan dalam Pasal 15 ayat (5).

Access to genetic resources assigns to national governments the authority to determine such access, which is subject to the prior informed consent of the provider country and the fair and equitable sharing of benefits. Recognizing both the sovereign rights and the inter-dependence of countries over their plant genetic resources for food and agriculture, the International Treaty establishes a multilateral system that aims to facilitate access and benefit sharing. 21

Ini berarti bahwa mereka yang ingin mendapatkan akses terhadap SDG harus mengadakan negosiasi untuk mencapai kesepakatan dengan Pemberi SDG. Kedua belah pihak diharapkan untuk menyepakati ketentuan tentang akses serta bentuk dari keuntungan yang akan dibagi. Kesepakatan-kesepakatan tersebut dapat diuraikan dalam perjanjian pengalihan material (MTA).

Setiap negara selalu bergantung pada satu sama lain dalam pemenuhan kebutuhan atas sumber daya genetik tanaman. Tidak ada negara yang mandiri dalam sumber daya genetik tanaman. Namun, terjadi ketidakseimbangan dalam distribusi sumber daya genetik tanaman di dunia. Negara-negara berkembang memiliki kekayaan berbagai sumber daya genetik tanaman dan mereka diharapkan untuk menjamin konservasi sumber daya genetik tanaman di wilayah mereka. Namun, menjamin konservasi sumber daya ini tidak tanpa biaya.

'If preservation were costless, then all genetic resources would be preserved (Roger A. Sedjo). ${ }^{22}$

Selain Convention on Biological Diversity, diatur lebih lanjut dalam Nagoya Protocol. Berdasarkan Pasal 6 Ayat (2) dan (3) Protokol Nagoya, hak berdaulat negara

20 Peter-Thobias Stoll, Acces to GRs and Benefit Sharing - Underlying Concepts and the Idea of Justice. Ebook Genetic Resources, Traditional Knowledge \& the Law. Earthscan in the UK and USA in 2009, p. 5 .

21 Graham Dutfield, 2004, Intellectual Property, Biogenetic Resources And Traditional Knowledge, Earthscan: London UK. 22 Abeba Tadasse Gebreselassie, Material Transfer Agreements on Teff and Vernonia-Ethiopian Plant Genetic Resources, Journal Politics and Law, December 2009, Vol. 2, No. 4, Demark: Aarhus University. 
untuk mengambil tindakan legislatif, administratif dan kebijakan sesuai dengan hukum nasional mengatur akses terhadap Sumber Daya Genetik dan Pengetahuan Tradisional. Protokol Nagoya mengharuskan negara melakukan pengakuan keberadaan Masyarakat Hukum Adat, hak-haknya serta hukum adat yang mengatur akses atas pengetahuan tradisional terkait Sumber Daya Genetik sepanjang sesuai dengan peraturan perundangundangan nasional. Hal ini termasuk memastikan Persetujuan Atas Dasar Informasi Awal (PADIA) atau Prior Informed Consent (PIC) dalam rangka melakukan akses tersebut.

Pembuatan kebijakan pengaturan akses atas Pengetahuan Tradisional terkait Sumber Daya Genetik sangat penting dalam rangka mencegah kepunahan Pengetahuan Tradisional, pemanfaatan tanpa ada PADIA atau izin (misappropriation dan misuse) khususnya dari pihak asing. Berdasarkan Pasal 7 Protokol Nagoya, negara harus mengambil tindakan legislatif, administratif dan kebijakan untuk memastikan Pengetahuan Tradisional diakses berdasarkan prior informed consent atau PADIA dan MAT (Mutual Agreed Terms) atau kesepakatan bersama.

Pasal 12 Protokol Nagoya merupakan pasal utama dalam pengaturan Pengetahuan Tradisional yang terkait dengan Sumber Daya Genetik. Pasal ini memandatkan negara untuk melibatkan secara efektif Masyarakat Hukum Adat dan untuk mendirikan balai kliring yang berfungsi mnginformasikan kepada calon pemanfaat Pengetahuan Tradisional mengenai kewajiban-kewajiban, termasuk detail pengaturan mengenai ABS (Access and Benefit Sharing)/Akses dan pembagian keuntungan.

Negara wajib memfasilitasi pengembangan:

a. Protokol dalam Masyarakat Hukum Adat dalam kaitannya dengan akses terhadap Pengetahuan Tradisional yang terkait dengan Sumber Daya Genetik.

b. Persyaratan minimum untuk melakukan kesepakatan bersama dalam rangka memastikan adanya pembagian keuntungan yang adil dan merata.

c. Model klausul untuk kesepakatan bersama mengenai pembagian keuntungan dari pemanfaatan Pengetahuan Tradisional yang terkait dengan Sumber Daya Genetik.

Negara, dalam melaksanakan Protokol Nagoya, tidak boleh melarang pemanfaatan secara tradisional dan pertukaran Sumber Daya Genetik dan Pengetahuan Tradisional terkait di dalam dan antara Masyarakat Hukum Adat. Pengaturan Acces and Benefit Sharing (ABS) di tingkat nasional dapat direalisasikan di tingkat legislatif, administratif maupun kebijakan pemerintah nasional yang sesuai dan konsisten dengan Instrument ABS.

Domestic-level benefit-sharing measures are to provide for the fair and equitable sharing of benefits arising from the utilization of genetic resources with the contracting party providing genetic resources. Utilization includes research and development on the genetic or biochemical composition of genetic resources, as well as subsequent applications and commercialization. Sharing is subject to mutually agreed terms. Benefits may be monetary or non-monetary such as royalties and the sharing of research results. ${ }^{23}$

Berkaitan dengan prior informed consent, bahwa: If the providing country's national law on access to biological material or use of traditional knowledge requires prior consent, the application shall state whether such consent has been obtained. If the providing country is not the same as the country of origin of the biological material or the traditional knowledge, the application shall also state the country of origin. ${ }^{24}$

Kewajiban peserta konvensi adalah mengambil langkah-langkah di tingkat domestik untuk menyediakan pembagian yang adil dan merata atas keuntungan yang diperoleh dari pemanfaatan sumber daya genetik dengan pihak yang menyediakan sumber daya genetik. Pemanfaatan (utilization) meliputi penelitian dan pengembangan pada gen atau komposisi biokimia dari sumber daya genetik, berikut penerapannya dan komersialisasinya. Pembagian keuntungan berdasarkan pada persyaratan yang disetujui bersama. Keuntungan dapat berupa royalti ataupun dalam bentuk bagi hasil penelitian.

Indonesia dan negara-negara yang pada umumnya negara berkembang memiliki demikian banyak spesies yang dapat dimanfaatkan itu melalui bioteknologi, ataupun melalui kultivasi lainnya, namun manfaat secara ekonomi masih belum dapat dirasakan karena lemahnya bergaining position dari negara berkembang yang kaya akan keanekaragaman hayati. Menurut Dutfield, ada beberapa alasan untuk itu: ${ }^{25}$

a. Pembagian keuntungan secara adil tidak mungkin atau tidak dapat diperkirakan;

b. Negara-negara saling tergantung tidak ada yang bisa memenuhi kebutuhannya sendiri;

c. Plasma nutfah terbesar merupakan koleksi ex situ;

d. Negara berkembang kekurangan ilmu pengetahuan dan teknologi dalam menangkap manfaat dari agro biodiversity.

Materal Transfer Agreement (MTA) merupakan salah satu bentuk mekanisme yang dapat memfasilitasi perjanjian pemanfaatan akses sumber daya genetik, bersifat sederhana, flexible dan negotiable. Pembagian keuntungan (benefit sharing) merupakan kesepakatan yang diatur dalam MTA berdasarkan kesepakatan para pihak (provider dan recipient). Begitupula mengenai hak-hak masyarakat tempatan (local communities) yang mempunyai hak atas pembagian keuntungan atas pemanfaatan sumber daya genetik. MTA juga mengatur mengenai Persetujuan atas dasar informasi awal (prior informed consent). Selain Nagoya Protocol, perjanjian internasional

23 Offficial website Convention on Biological Diversity http://www. cbd.int/abs/about/\#objective diakses 24 Januari 2014 Pukul 11:01. 24 Jorge Cabrera Medaglia et all, The Intercafe between the Nagoya Protocol on ABS and the ITPGRFA at the International Level: Potential Issues for Consideration in Supporting Mutually Supportive Implementation at the National Level, Fridtjof Nansen Institute 2013, Lysaker, Norway, hal 5.

25 Graham Dutfield, 2002, Intellectual Property Rights and Traditional Knowledge, Paper for the ASEAN Workshop on the TRIPS Agreement and Traditional Medicine, Jakarta: 13-15 February 2001, hal 5-6. 
yang mendukung adanya pelaksanaan material transfer agreemant terdapat dadalah International Treaty on Plant Genetic Resources for Food and Agriculture (ITPGRFA).

Dalam kerangka menyelaraskan CBD, Food and Agriculture Organization (FAO) menetapkan Perjanjian mengenai Sumber Daya Genetik Tanaman Pangan dan Pertanian (International Treaty on Plant Genetic Resources for Food and Agriculture) yang bertujuan untuk mendukung ketahanan pangan dan pertanian yang berkelanjutan melalui konservasi dan pemanfaatan secara berkelanjutan Sumber Daya Genetik Tanaman Pangan dan Pertanian (SDGTPP) dan pembagian keuntungan secara adil dan merata; kemudian melindungi Hak Petani yang didasarkan oleh sumbangan dan andil petani serta masyarakat setempat di pusat asal dan pusat keanekaragaman tanaman pertanian. ITPGRFA merupakan perjanjian internasional yang menetapkan dan menerapkan internasional ABS rezim multilateral system untuk akses sumber daya genetik tanaman untuk pangan dan pertanian.

Di dalam ITPGRFA para pihak sepakat bahwa akses yang difasilitasi pada sumber daya genetik tanaman untuk pangan dan pertanian menurut Sistem Multilateral. Menurut perjanjian ini, Penerima (recipient) tidak diperkenankan menuntut hak kekayaan intelektual apapun atau hak lain yang dapat membatasi akses yang difasilitasi terhadap sumber daya genetik tanaman untuk pangan dan pertanian, atau bagian atau komponen genetik, dalam bentuk yang diterima dari Sistem Multilateral. Pasal 12 ayat (4) memerintahkan bahwa setiap akses yang difasilitasi, sesuai dengan ketentuan Pasal 12 ayat (2) dan ayat (3), wajib disediakan menurut perjanjian pengalihan materi/PPM baku (standard material transfer agreement).

Material transfer agreement merupakan salah satu cara untuk mengamankan sumber daya genetik, yaitu suatu kesepakatan yang substansinya tunduk pada persetujuan para pihak. MTA digunakan ketika pemilik materi (provider) bersedia untuk memberikan izin kepada recipient atas pemanfaatan materi biologi. Perjanjian ini merupakan mekanisme untuk memfasilitasi kerjasama penelitian dan pengembangan di bidang bioteknologi, seperti sumber daya genetik. Melalui MTA, pengiriman materi sumber daya genetik akan menjadi lebih jelas dan resmi, karena itu pula di dalam MTA akan mengatur beberapa hal terkait intellectual property rights, sehingga diharapkan adanya MTA dapat mencegah biopiracy dan misappropriation.

Menurut W. Lesser: MTAs are being used when the owners of the materials are known and willing to provide use permission at least conditionally. MTAs, however, are of limited use when the ownership of the material has not been clearly established, such as with much material found in the wild and even with, say, landraces, the seeds of which are sold in local markets as food. ${ }^{26} A$ general expectation is that MTAs will probibit/ delay exchange, or at minimum will formalize the arrangements among researchers between the public and privat sectors. most often these concerns are associated specifically with IPR and/or biotechnology, but similar considerations would apply to MTAs. ${ }^{27}$

26 W. Lesser, Op. Cit. hal 29

27 Ibid, hal 31
Menurut W. Lesser, a simple MTA would allow research use only and contain three pricipal aspects.28

a. A description of the material

b. A statement that only research use is permitted; commercialization would require an additional agreement.

\section{c. An agreement probibiting distribution to third party}

WIPO telah memberikan contoh provisions yang dapat digunakan dalam penyusunan draft kontrak antara provider dengan recipient sebagai berikut: ${ }^{29}$

\section{a. Para pihak}

Biasanya dalam MTA disebut sebagai provider dan recipient. Provider merupakan pihak yang menyediakan materi untuk diserahkan kepada pihak lain dengan perjanjian tersebut. Recipient adalah pengguna materi untuk tujuan komersial maupun non komersial, dalam konteks penelitian disebut sebagai bioprospector.

b. Ruang lingkup yang diperjanjikan (scope of contract)Dalam hukum perdata biasanya sering disebut sebagai obyek perjanjian. Definisi mengenai obyek yang diperjanjikan ini harus jelas karena menyangkut batasan dalam penggunaan materi. Misalnya obyek perjanjian tersebut mengenai genetic materials, apakah definisi genetic material tersebut mencakup pula derivatives, progency (turunan) dan isolated substances dari materials tersebut, atau mengacu sebagaimana yang di dalam Article 2 CBD. Selain itu, kontrak harus mencakup pengetahuan tradisional yang terkait dengan pemanfaatan genetic materials yang menjadi obyek perjanjian.

c. Kewajiban provider

Pihak provider biasanya adalah pemerintah yang mewakili masyarakat pemilik sumber daya genetik. Kewajiban provider ialah menyediakan materi yang diperjanjikan tersebut kepada recipient, menghubungkan recipient dengan masyarakat lokal pemilik pengetahuan tradisional.

d. Kewajiban recipient

Sebagai imbalan dari akses pengalihan material, recipient dapat dibebani kewajiban-kewajiban seperti informasi yang jelas mengenai penelitian dan pengembangan yang dilakukan tersebut, sekaligus dengan aspek komersial nya. Recipient juga dapat dibebankan pembayaran imbalan atas keuntungan yang ia peroleh (benefit sharing), benefit sharing juga diberikan dalam bentuk non monetary dan lain-lain.

e. Jaminan bagi masyarakat lokal

Adanya jaminan bahwa masyarakat lokal masih

28 Ibid, hal 29.

29 WIPO Secretariat, “ Operational Principles for Intellectual Property Clauses of Contractual Agreements Concerning Access to Genetic Resources and Benefit Sharing”, WIPO Intergovernmental Committee on Intellectual Property and Genetic Resources, Traditional Knowledge and Foklore, (WIPO/GRTKF/IC/2/3, 10 September 2001), 22-44. 
tetap dapat memanfaatkan sumber daya genetik dan pengetahuan tradisional tersebut meskipun kelak akan diberikan paten atas penggunaan sumber daya genetik tersebut. Sebagaimana diatur dalam Pasal 10 (c) CBD.

f. Berakhirnya perjanjian

Lamanya perjanjian dan berakhirnya kontrak jika terjadi sengketa. WIPO menawarkan lembaga arbitrase sebagai media penyelesaian sengketa tersebut. Namun sengketa ini tidak hanya melibatkan pihak provider dan recipient, tetapi juga ada masyarakat lokal. Oleh sebab itu, lembaga arbitrase dianggap kurang tepat dan sebaiknya sengketa diselesaikan oleh lembaga peradilan. ${ }^{30}$

\section{Instrumen Hukum Nasional}

Kerangka regulasi dalam CBD, Nagoya Protocol, ITPGRFA dan yang ditujukan kepada setiap negara peserta adalah agar strategi, kebijakan dan langkah-langkah yang akan dilaksanakan di tingkat nasional sesuai dengan perjanjian internasional tersebut. Para Pihak harus membuat undang-undang dan mengadopsi kebijakan yang sesuai. Rincian dari kebijakan yang diambil oleh negara-negara mungkin akan berbeda, tergantung pada kebutuhan, kapasitas dan pilihan masing-masing negara. Indonesia merupakan peserta CBD dan Traktat FAO. Dalam rangka untuk memenuhi kewajibannya, Indonesia telah meratifikasi CBD, ITPGRFA dan Nagoya Protocol.

Indonesia telah mengesahkan United Nations Convention on Biological Diversity melalui Undangundang No. 5 tahun 1994 pada tanggal 1 Agustus 1994. Hal ini bertujuan untuk memberikan jaminan bahwa Pemerintah Indonesia dapat menggalang kerja sama di bidang teknis ilmiah baik antarsektor pemerintah maupun dengan sektor swasta, di dalam dan di luar negeri. Hadirnya undang-undang ini juga bertujuan untuk pengembangan dan penanganan bioteknologi sehingga Indonesia tidak dijadikan ajang uji coba pelepasan organisme yang telah direkayasa secara bioteknologi oleh negara-negara lain; pengembangan sumber dana untuk penelitian dan pengembangan keanekaragaman hayati Indonesia. Dengan menjadi anggota dari Convention on Biological Diversity, Indonesia akan melakukan pengembangan kerja sama internasional untuk peningkatan kemampuan dalam konservasi dan pemanfaatan keanekaragaman hayati.

Dengan meratifikasi Konvensi ini diharapkan Indonesia tidak akan kehilangan kedaulatan atas sumber daya alam keanekaragaman hayati yang dimiliki. Konvensi ini mengakui bahwa negara-negara, mempunyai hak berdaulat untuk memanfaatkan sumber daya alam keanekaragaman hayati secara bekelanjutan sejalan dengan keadaan lingkungan serta sesuai dengan kebijakan pembangunan dan tanggung jawab masingmasing sehingga tidak merusak lingkungan.

Indonesia juga mengesahkan International Treaty on Plant Genetic Resources for Food and Agriculture melalui UU No. 4 Tahun 2006 pada tanggal 20 Maret 2006. Indonesia menjadi pihak dari perjanjian ITPRFGA, sehingga berimplikasi pada kewajiban terkait pelaksanaan 30 Agus Sardjono, 2006, Hak Kekayaan Intelektual dan Pengetahuan Tradisional, Bandung: PT. Alumni, hal 280. system multilateral sumber daya genetik tanaman yang membentuk system akses dan pembagian keuntungan antar pihak dengan dengan hak resiprokal minimum.

Dengan menjadi pihak dari perjanjian ini akan berimplikasi pada sejumlah kewajiban bagi Indonesia yaitu terkait pelaksanaan sistem multilateral sumber daya genetik tanaman yang membentuk sistem akses dan pembagian keuntungan antar pihak dengan dengan hak resiprokal minimum. Kewajiban Indonesia adalah:

a. Menyediakan akses pada SDG yang relevan kepada pihak lain

b. Menjamin dalam domestic law bahwa standard MTA SDG yang telah ditetapkan dapat diterapkan.

c. Penerapan pembagian keuntungan yg adil dari pemanfaatan SDG yang diakses secara Multilateral

d. Memberikan informasi dan fasilitas tentang pemanfaatan SDG yang tercantum dalam system Multilateral.

e. Wajib menerapkan perlindungan Intellectual Property Rights yang melekat pada sumber daya genetik pada tumbuhan, informasi ataupun tekologi yang diterima dari Multilateral System.

Mengenai sistem multilateral dari akses dan pembagian keuntungan, Para Pihak mengakui hakhak berdaulat negara-negara atas sumber daya genetik tanaman untuk pangan dan pertanian mereka sendiri, termasuk bahwa kewenangan untuk menentukan akses ke sumber daya tersebut terletak pada pemerintah nasional dan tergantung pada perundang-undangan nasional . CBD mengharuskan negara untuk memantau pelaksanaan perjanjian transfer material. Pemantauan dapat mencakup aplikasi untuk hak kekayaan intelektual yang berkaitan dengan bahan yang disediakan. Selain itu, negara-negara dapat mendorong pengguna untuk mengungkapkan negara asal sumber daya genetik tanaman dalam aplikasi mereka untuk hak kekayaan intelektual.

Indonesia juga baru saja mengesahkan Nagoya Protocol On Access To Genetic Resources and the Fair And Equitable Sharing of Benefits Arising from Their Utilization to the Convention on Biological Diversity (Protokol Nagoya Tentang Akses pada Sumber Daya Genetik dan Pembagian Keuntungan yang Adil dan Seimbang yang Timbul dari Pemanfaatannya atas Konvensi Keanekaragaman Hayati) melalui UndangUndang Nomor 11 Tahun 2013.

Pada umumnya, setiap Sumber Saya Genetik (SDG) selalu memiliki keterkaitan dengan Pengetahuan Tradisional (PT) tertentu, misalnya Pengetahuan Tradisional tentang manfaat dari tanaman tertentu yang dapat mengobati beberapa jenis penyakit. Dengan lahirnya Undang-undang RI Nomor 32 Tahun 2009 tentang Perlindungan dan Pengelolaan Lingkungan Hidup khususnya Pasal 63 ayat (1) pemerintah berkepentingan untuk mengembangkan kebijakan pengelolaan Pengetahuan Tradisional sebagai bagian dari perlindungan kearifan lokal, mengendalikan pemanfaatan Pengetahuan Tradisional yang terkait 
dengan Sumber Daya Genetik, dan menjamin pemenuhan hak masyarakat termasuk Masyarakat Hukum Adat untuk berperan serta dalam perlindungan dan pengelolaan Pengetahuan Tradisional khususnya yang terkait dengan Sumber Daya Genetik. Kebijakan ini sangat dibutuhkan terlebih dengan diadopsinya Protokol Nagoya pada pertemuan COP X di Nagoya, bulan Oktober tahun 2010. ${ }^{31}$

Pengaturan mengenai akses sumber daya genetik dan pembagian keuntungan atas pemanfaatan SDG didukung oleh Undang-Undang No. 32 Tahun 2009 tentang Perlindungan dan Pengelolaan Lingkungan Hidup. Undang-undang ini memiliki peranan dalam pengemban kebijakan Pengetahuan Tradisional terkait Sumber Daya Genetik. Di dalam Pasal 63 Ayat (1) huruf(i) Undang-Undang No. 32 Tahun 2009 menyatakan bahwa dalam perlindungan dan pengelolaan lingkungan hidup, Pemerintah bertugas dan berwenang: menetapkan dan melaksanakan kebijakan mengenai Sumber Daya Alam Hayati dan non hayati, keanekaragaman hayati, Sumber Daya Genetik, dan keamanan hayati produk rekayasa genetik. Sedangkan di dalam Pasal 63 ayat (1) huruf $(\mathrm{t})$ Undang-undang RI Nomor 32 Tahun 2009 Tentang Perlindungan dan Pengelolaan Lingkungan Hidup dinyatakan bahwa dalam perlindungan dan pengelolaan lingkungan hidup, pemerintah bertugas dan berwenang: menetapkan kebijakan mengenai tata cara pengakuan keberadaan Masyarakat Hukum Adat, kearifan lokal, dan hak masyarakat hukum adat yang terkait dengan perlindungan dan pengelolaan lingkungan hidup.

Selanjutnya, rezim baru Undang-Undang Paten yaitu melalui Undang-Undang 13 Tahun 2016 juga telah mengakomodasi perlindugan sumber daya genetik sebagai sumber dari penemuan paten. Undang-Undang Paten terbaru mengatur tentang Keharusan pengungkapan dengan jelas dan benar asal sumber daya genetik dan/atau pengetahuan tradisional dalam deskripsi paten (Nagoya Protokol utk ABS) dan Pembagian hasil dan/atau akses pemanfaatan sumber daya genetik dan/atau pengetahuan tradisional sesuai dengan peraturan perundangundangan dan perjanjian internasional di bidang sumber daya genetik dan pengetahuan tradisional. Ketentuan ini memberikan pengakuan adanya kedaulatan negara sebagai pihak yang berwenang untuk menentukan akses sumber daya genetik berdasarkan peraturan perundangundangan yang berlaku di negara di mana sumber daya genetik berasal, yaitu Indonesia. Dalam hal ini, UndangUndang Nomor 13 Tahun 2016 tentang Paten, telah mendukung maksud dan tujuan sebagaimana diatur dalam Protokol Nagoya, antara lain:

a. Memberikan akses dan pembagian keuntungan terhadap pemanfaatan sumber daya genetik dan pengetahuan tradisional terkait sumber daya genetik, termasuk pemanfaatan atau komersialisasinya serta produk turunannya (derivative);

\section{b. Akses terhadap sumber daya genetik tersebut}

31 Kertas Posisi (White Paper): Pengetahuan Tradisional Sebagai Bagian Kearifan Lokal Dari Masyarakat Hukum Adat Yang Terkait Dengan Sumber Daya Genetik (Sdg) Dalam Protokol Nagoya, Kementerian Lingkungan Hidup Deputi Bidang Komunikasi Lingkungan Dan Pemberdayaan Masyarakat Tahun 2011. tetap mengedepankan kedaulatan negara dan disesuaikan dengan hukum nasional dengan berlandaskan prinsip prior informed consent (PIC) dengan pemilik atau penyedia sumber daya genetik; dan

c. Mencegah pencurian sumber daya genetik (biopiracy).

Dengan demikian, ketentuan mengenai pemanfaatan sumber daya genetik dalam Undang-Undang 13 Tahun 2016 tentang Paten masih perlu pengaturan yang lebih detail dan bahkan lebih teknis dalam peraturan yang lebih rendah atau aturan pelaksanaannya. Salah satu upaya dalam melindungi Paten yang memanfaatkan sumber daya genetik adalah lembaga yang berwenang mengatur tentang proses pendaftaran paten yang memanfaatkan sumber daya genetik dan pembagian keuntungan antara penemu, negara pemilik Sumber Daya Genetik dan juga masyarakat lokal. Upaya lain yang dapat dilakukan adalah melalui Mutual Agreed Terms.

Kesepakatan bersama atau Mutual Agreed Terms (MAT) adalah perjanjian tertulis yang berisi persyaratan dan kondisi yang disepakati antara penyedia dan pemohon akses berdasarkan prinsip kebebasan berkontrak (freedom of contract). Kontrak bersama harus dapat memberikan kepastian dan kejelasan, meminimalisasi biaya transaksi dan menaati peraturan yang berlaku. Berdasarkan Pasal 7 Protokol Nagoya, negara harus mengambil tindakan legislatif, administratif dan kebijakan untuk memastikan Pengetahuan Tradisional dapat diakses berdasarkan PIC/PADIA dan MAT (kesepakatan bersama). Pembagian keuntungan yang dimaksud adalah kegiatan pendistribusian keuntungan secara finansial (moneter) dan atau non finansial (non moneter) yang berasal dari penelitian, pengembangan, komersialisasi atau pemberian lisensi (atau bentuk-bentuk pemanfaatan lainnya) sebagai hasil dari akses terhadap Pengetahuan Tradisional terkait Sumber Daya Genetik.

Pedoman kesepakatan bersama antara penyedia dan pengguna dibuat secara sukarela, khususnya klausula mengenai Masyarakat Hukum Adat dan Pengetahuan Tradisional. Pemerintah dapat mengembangkan dan mendorong penggunaan perjanjian standar yang bertujuan untuk melindungi kepentingan Masyarakat Hukum Adat dan masyarakat lokal. Klausula sebaiknya dapat mendefinisikan secara tegas hak dan kewajiban penyedia (provider) dan pengguna (recipient). Pembuatan pedoman standar minimum pembagian keuntungan. Kebijakan ini didasarkan pada Pasal 19 Protokol Nagoya yaitu untuk mendorong pengembangan dan penggunaan model klausul kontrak sektoral dan lintassektoral untuk Kesepakatan bersama. Material Transfer Agreement merupakan salah satu mekanisme yang dapat memfasilitasi akses sumber daya genetik dan mengatur mengenai pembagian keuntungan yang adil dan seimbang.

Perkembangan penelitian di bidang biologi modern, terutama dalam hal bioprospeksi semakin meningkat. Diperkirakan akan semakin banyak sampel/spesimen flora dan fauna yang akan dibawa ke luar Indonesia dan diduga tidak hanya digunakan untuk keperluan penelitian, namun juga untuk kepentingan komersial. ${ }^{32}$ 32 M. Ahkam Subroto dan Suprapendi, Aspek-Aspek Hak Kekayaan 
Bioprospeksi merupakan rangkaian kegiatan termasuk koleksi, riset dan penggunaan sumberdaya genetik secara sistematis untuk mendapatkan komposisi kimia baru, gen, organisme dan produk alamiah untuk tujuan ilmiah dan/atau komersial. ${ }^{33}$ Dalam kerjasama bioprospeksi paling sedikit terlibat 2 pihak dimana satu pihak bertindak sebagai penyedia sumber daya genetik (biasanya negara berkembang seperti Indonesia) dan pihak lain bertindak sebagai pemanfaat sumber daya genetik tersebut (biasanya institusi atau perusahaan dari negara maju yang menguasai teknologi tinggi).$^{34}$ Bentuk kerjasama penelitian ini disepakati dalam bentuk dokumen perjanjian transfer material (Material Transfer Agreement).

Di Indonesia, pengaturan mengenai material transfer agreement diatur lebih spesifik dalam Peraturan Menteri Pertanian No. 15/Permentan/OT.140/3/2009 tentang Pedoman Penyusunan Material Transfer Agreement dan Peraturan Menteri Kesehatan No. 657/Menkes/Per/ VIII/2009 tentang Pengiriman dan Penggunaan Spesimen Klinik, Materi Biologik dan Muatan Informasinya. Kedua peraturan ini memberikan pedoman mengenai pembuatan kontrak MTA antara recipient dan provider didalam negeri maupun diluar negeri, untuk tujuan penelitian dan pengembangan secara non komersial maupun komersial.

Dua Peraturan Menteri tersebut adalah untuk memfasilitasi akses terhadap SDG bagi penelitian dasar dan terapan. Disamping itu MTA merupakan dasar penetapan hak negara Pemberi dan Masyarakat Tempatan. Tujuan ditetapkannya Pedoman ini ialah untuk melindungi genetic resources dan derivatnya asal Indonesia dan memastikan agar kegiatan penelitian dan pengembangan serta penerapan teknologi tidak menimbulkan kerugian bagi kesehatan dan keselamatan manusia, kelestarian fungsi lingkungan hidup, kerukunan bermasyarakat dan keselamatan bangsa.

Secara umum, didalam peraturan ini terdapat ketentuan standard material transfer agreement bahwa, Pemberi wajib mengalihkan SDG atau invensi kepada Penerima hanya untuk penelitian (non-eksklusif atau non-komersial) atau (penelitian eksklusif atau komersial) sesuai dengan tujuan pengalihan. Penerima wajib memberikan kompensasi kepada Pemberi. Penerima juga wajib memberikan sejumlah presentase (royalti) dari total pendapatan akibat komersialisasi produk yang dihasilkan dari SDG yang dialihkan, dan keuntungan lain sebagaimana disebutkan dalam MTA. Pemberi berhak mendapatkan persentase dari total pendapatan yang berasal dari komersialisasi SDG yang dialihkan dan keuntungan lain. Penerima berhak memanfaatkan SDG yang dialihkan untuk tujuan penelitian dan pengembangan (non-komersial) atau komersial sesuai dengan tujuan pengalihan. Apabila Penerima memperoleh kekayaan intelektual yang dikembangkan dari SDG yang diterimanya dan mempunyai potensi komersial. Penerima berhak mencari peluang untuk mengembangkan kekayaan intelektual tersebut menjadi

Intelektual dalam Penyusunan Perjanjian Penelitian dengan Pihak Asing di Bidang Biologi, Makalah Rapat Tim Koordinasi Pemberian Ijin Penelitian, LIPI, Jakarta 16 Oktober 2001. hal 1.

33 Hilman dan Romadoni, 2001, dalam M. Ahkan Subroto dan Suprapendi, Ibid hal 2.

34 Loc. Cit. produk komersial atau melisensikan kekayaan intelektual tersebut kepada perusahaan swasta.

Dari dua Peraturan Menteri Pertanian dan Peraturan Menteri Kesehatan tersebut, merupakan bentuk upaya utuk melindungi sumber daya genetik dari missappropriation atau biopiracy, serta mendapatkan pembagian keuntungan dari hasil penelitian bagi Negara maupun masyarakat lokal. Dua peraturan metnteri tersebut merupakan contoh upaya yang dapat dilakukan untuk melindungi Sumber Daya Genetik di Indonesia. Atas berbagai instrumen hukum internasional, terutama yang telah diratifikasi Indonesia mengatur mengenai akses sumber daya genetik yang hak kedaulatannya dimiliki oleh setiap negara peserta. Oleh karena itu setiap negara wajib membuat regulasi/ketentuan yang dapat mendukung akses sumber daya genetik dan pembagian keuntungan yang adil dan seimbang, serta ketentuan mengenai multilateral sistem sebagaimana yang diatur dalam ITPGRFA. Atas alasan itu pula, Negara dapat mengatur dan menentukan upaya-upaya bagi pemanfaatan sumber daya genetik yang tentu berkaitan dengan perlindungan Hak Kekayaan Intelektual.

\section{E. SIMPULAN}

Undang-Undang Nomor 13 Tahun 2016 tentang Paten telah mengatur upaya perlindungan Sumber Daya Genetik dalam kaitannya dengan paten yang memanfaatkan sumber daya genetik di Indonesia. Hal ini sejalan dengan tujuan Convention on Biological Diversity dan Nagoya Protocol yang mengatur tentang keharusan pengungkapan dengan jelas dan benar asal sumber daya genetik dan/atau pengetahuan tradisional dalam deskripsi paten. Selanjutnya dinyatakan juga bahwa pembagian hasil dan/atau akses pemanfaatan sumber daya genetik dan/atau pengetahuan tradisional dilaksanakan sesuai dengan peraturan perundangundangan dan perjanjian internasional di bidang sumber daya genetik dan pengetahuan tradisional. Meski demikian, ketentuan dalam Undang-Undang Nomor 13 Tahun 2016 tentang Paten ini masih perlu peraturan pelaksana yang mengatur perlindungan Sumber Daya Genetik lebih teknis, baik dalam hal prior informed consent dan ketentuan tentang pemberian akses dan pembagian keuntungan terhadap pemanfaatan sumber daya genetik

Convention on Biological Diversity dan Nagoya Protocol telah mengakui hak kekuasaan negara atas sumber daya alamnya, sehingga kekuasaan untuk menentukan akses terhadap Sumber Daya Genetik berada di tangan pemerintah dan bergantung pada undang-undang negara yang berlaku. Selain Nagoya Protocol, perjanjian internasional yang mendukung adanya perlindungan Sumber Daya Genetik terdapat dalam International Treaty on Plant Genetic Resources for Food and Agriculture (ITPGRFA). Ketentuan dalam instrumen-instrumen hukum internasional itu mendukung agar tiap-tiap negara peserta strategi, kebijakan dan langkah-langkah yang akan dilaksanakan di tingkat nasional sesuai dengan perjanjian internasional tersebut. Para Pihak harus membuat undang-undang dan mengadopsi kebijakan yang sesuai. Demikian pula Indonesia yang telah meratifikasi perjanjian-perjanjian internasional tersebut harus dapat membuat kebijakan 
atau regulasi tentang pemanfaatan Sumber Daya Genetik dan pembagian keuntungan atas Sumber Daya Genetik sebagai sumber dari penemuan Paten. Salah satu upaya yang dapat dilakukan oleh Indonesia yang sesuai dengan instrumen hukum Internasional adalah membuat kebijakan tentang Material Transfer Agreement.

\section{F. DAFTAR PUSTAKA}

\section{Buku}

1. Abdulkadir Muhammad, 2001, Kajian Hukum Ekonomi Hak Kekayaan Intelektual, Bandung: PT Citra Aditya Bakti.

2. Agus Sardjono, 2009, Membumikan HKI di Indonesia, Bandung: CV Nuansa Aulia.

3. Agus Sardjono, 2006, Hak Kekayaan Intelektual dan Pengetahuan Tradisional, Bandung: PT. Alumni.

4. Adrian Sutedi, 2009, Hak Atas Kekayaan Intelektual, Jakarta: Sinar Grafika.

5. Afrillyana Purba,dkk, 2005, TRIPS-WTO dan Hukum HKI Indonesia Kajian Perlindungan Hak Cipta Seni Batik Tradisional Indonesia, Jakarta: Rineka Cipta.

6. Johny Ibrahim, 2005, Teori dan Penelitian Hukum Normatif, Malang: Bayu Media.

7. Krisnani Setyowati, dkk. 2005, Hak Kekayaan Intelektual dan Tantangan Implementasinya di Perguruan Tinggi, Bogor: Kantor HKI - Institut Pertanian Bogor.

8. Miranda Risang, Harry Alexander, dan Wina Puspitasari, 2014, Sumber Daya Genetik, Pengetahuan Tradisiona dan Ekspresi Budaya Tradisional di Indonesia, Bandung: PT. ALUMNI.

9. Muhammad Djumhana \& Djubaedillah, 2003, Hak Milik Intellektual, Sejarah, Teori dan Prakteknya di Indonesia. Bandung: PT Citra Aditya Bakti.

10. Paul Marett, 1996, Intellectual Property Law, London, United Kingdom: Sweet \& Maxwell Ltd.

11. Peter Mahmud Marzuki, 1996, Kajian Hukum Terhadap Hak atas Kekayaan Intelektual, Surabaya.

12. Peter-Thobias Stoll, Acces to GRs and Benefit Sharing - Underlying Concepts and the Idea of Justice. Ebook Genetic Resources, Traditional Knowledge \& the Law. Earthscan in the UK and USA in 2009.
13. Ranti Fauza Mayana, 2004, Perlindungan Desain Industri Di Indonesia Dalam Era Perdagangan Bebas, Jakarta: Grasindo

14. Ronny Hanitijo Soemitro, Metodologi Penelitian Hukum dan Jurimetri, Ghalia Indonesia, Jakarta, 1990

15. S. Von Lewinski, 2004, Indigenous Heritage and Intellectual Property Genetic Resouces, Traditional Knowledge and Folklore. Netherlands: Kluwer Law International..

16. Soerjono Soekanto dan Sri Mamudji, 2010, Penelitian Hukum Normatif Suatu Tinjauan Singkat, Jakarta: PT. Raja Grafindo Persada.

17. W. Lesser, 1998, Sustainable use of Genetic Resources under the Convention on Biological Diversity, Exploring access and Benefit Sharing Issues. New York: CAB International.

\section{Jurnal, Artikel dan Karya Ilmiah}

1. Abeba Tadasse Gebreselassie, Material Transfer Agreements on Teff and Vernonia-Ethiopian Plant Genetic Resources, Journal Politics and Law, December 2009, Vol. 2, No. 4, Demark: Aarhus University.

2. Arimbi Heroepoetri. 1998. Makalah " Aspek Hukum Hak Kekayaan Intelektual dan Masyarakat Adat : Prospek, Peluang dan Tantangan

3. Bennett, Streitz \& Gacel, 2007, Specific Issues with Material Transfer Agreements, Handbook of Best Practice, MIHR: Oxford, U.K. and PIPRA: Davis, U.S.A. Available online www.ipHandbook.org.

4. Candra Purnama, 2016, Implementasi UndangUndang No. 11 Tahun 2013 Dalam Mengatasi Biopiracy Di Indonesia, eJournal Ilmu Hubungan Internasional, 2016, 4 (1) 129-142 ISSN 2477-2623, ejournal.hi.fisip-unmul.ac.id.

5. Charless Lawson, Intellectual property and the material transfer agreement under the International Treaty on Plant Genetic Resources for Food and Agriculture, European Intellectual Property Review, E.I.P.R. 2009, 31(5)

6. Daniel M. Putterman, 1996, Model Material Transfer Agreement for Equitable Biodiversity Prospecting, Heinonline, Citation: 7 Colo. J. Int'l Envtl. L. \& Pol'y 149.

7. Dede Mia Yusanti, Perlindungan Sumber Daya 
Genetik Melalui Sistem Hak Kekayaan Intelektual, Direktorat Jenderal Hak Kekayaan Intelektual - Departemen Hukum dan HAM RI. TangerangBanten 8 Nov 2006.

8. Graham Dutfield, 2002, Intellectual Property Rights and Traditional Knowledge, Paper for the ASEAN Workshop on the TRIPS Agreement and Traditional Medicine, Jakarta: 13-15 February 2001.

9. Graham Dutfield, 2004, Intellectual Property, Biogenetic Resources And Traditional Knowledge, Earthscan: London UK.

10. Jorge Cabrera Medaglia et all, The Intercafe between the Nagoya Protocol on ABS and the ITPGRFA at the International Level: Potential Issues for Consideration in Supporting Mutually Supportive Implementation at the National Level, Fridtjof Nansen Institute 2013, Lysaker, Norway.

11. Kementerian Lingkungan Hidup, 2011, Deputi Bidang Komunikasi Lingkungan dan Pemberdayaan Masyarakat, Kertas Posisi (white paper), Pengetahuan Tradisional Sebagai Bagian Kearifan Lokal dari Masyarakat Hukum Adat yang Terkait Dengan Sumber Daya Genetik (SDG) Dalam Protokol Nagoya, Jakarta.

12. M.Ahkam Subroto dan Suprapedi, Aspek-Aspek Hak Kekayaan Intelektual Dalam Penyusunan Perjanjian Penelitian dengan Pihak Asing di Bidang Biologi, Sentra HaKI-LIPI, Makalah Diskusi Disampaikan dalam "Rapat Tim Koordinasi Pemberian Ijin Penelitian”, LIPI, Jakarta, 16 Oktober 2001. http:// www.jaist.ac.jp/ witarto/paper/peneliti_asing.pdf diakses pada 27 November 2013.

13. Laporan Misi Pencarian Fakta atas HaKI dan Pengetahuan Tradisional, http://www.wipo.org, diakses pada tanggal 1 November 2012.

14. Report of the Royal Commission of Aboriginal Peoples, Canada Communications Group 454 (Ottawa, Vol. 4, 1996).

15. Retna Gumanti, Perlindungan Hukum Terhadap Hak Paten Di Indonesia, Al-Mizan, ISSN 19070985 E ISSN 2442-8256 Volume 11 Nomor 1 Juni 2015 Halaman 196-210.

16. Ria Budiningsing, Makna Keberhasilan Pembatalan Paten Shiseido, Kompas, Rabu 17 Juli 2002.

17. Syayana Kadidal, "Subject Matter Imperialism? Biodiversity, Foreign Prior Art and the Neem Patent Controversy", The Journal of Law and Technology,
(Vol 37, No. 2), 371-378.

\section{Peraturan Perundang-Undangan dan Perjanjian Internasional}

1. Konvensi Keanekaragaman Hayati (Convention on Biological Diversity (CBD) 1992.

2. Agreement on Trade Related Aspect of Intelectual Property Rights (TRIPs Agreement 1994). GENEVA: WIPO.

3. Perjanjian Internasional tentang Sumber Daya Genetik Tanaman untuk Pangan dan Pertanian (International Treaty on Plant Genetic resources for Food and Agriculture (ITPGRFA) tahun 2004.

4. Nagoya Protocol on Access to Genetic Resources and the Fair and Equitable Sharing of Benefits Arising from their Utilization to the CBD tahun 2010.

5. Undang-Undang No 5 tahun 1994 Tentang Pengesahan United Nations Convention On Biological Diversity (Konvensi Perserikatan Bangsa Bangsa Mengenai Keanekaragaman Hayati).

6. Undang-Undang No 4 tahun 2006 Tentang Pengesahan International Treaty On Plant Genetic Resources For Food and Agriculture (Perjanjian Mengenai Sumber Daya Genetik Tanaman Untuk Pangan dan Pertanian).

7. Undang-Undang No 13 Tahun 2016 tentang Paten 